\title{
El discurso científico sobre el papel: la importancia de la redacción de tareas
}

\author{
Lorenzo, M. Gabriela ${ }^{1}$
}

Recibido: 24/09/2016

Aprobado: 01/11/2016

\section{Resumen}

La formación docente de profesores universitarios en actividad debe ser pensada de manera singular, vinculada a sus propias prácticas disciplinares. Esto implica un desafío a la hora de presentar propuestas que resulten estimulantes y novedosas para ellos y que a su vez, les permitan recuperar su experiencia como estudiantes. En este trabajo presentamos una actividad diseñada en el marco de la asignatura Didáctica y Epistemología de las Ciencias de la Salud en la Carrera Docente de la Facultad de Farmacia y Bioquímica de la Universidad de Buenos Aires y que ha sido implementada en numerosos dispositivos de formación y capacitación docente. Presentaremos inicialmente los fundamentos teóricos que fundamentaron su diseño, relativos al lenguaje científico y a las competencias comunicativas de los profesores y los alumnos, para a continuación discutir sobre la actividad y mostrar algunos resultados de su implementación que ponen contundentemente en evidencia la importancia de la redacción de las consignas en la calidad de los aprendizajes que se promueven en los estudiantes.

Palabras Claves: Formación docente, Educación Alimentaria Nutricional, Programa Nacional de Formación Permanente, Vínculos Universidad-Institutos de Formación docenteEstablecimientos de nivel inicial, Educación para las primeras infancias.

\footnotetext{
${ }^{1}$ Universidad de Buenos Aires, Facultad de Farmacia y Bioquímica. Centro de Investigación y Apoyo a la Educación Científica. CONICET. Ciudad Autónoma de Buenos Aires, Argentina. Junín 956 (C.P. 1113).

glorenzo@ffyb.uba.ar
} 


\section{Sumary}

Faculty pedagogical education should be thought in a particular way very close to its own disciplinary practices. It implies a challenge in order to propose stimulating and fresh activities that allow their experiences as students were recovered. In this work, an activity designed in the framework of subject of teachers' training program of Facultad de Farmacia y Bioquímica of Universidad de Buenos Aires is presented. It has been applied in several formative and refreshing courses for teachers. First, theoretical bases about scientific language and communicative competences are described. Then, activity design and findings are discussed. Finally, results utterly shown the relevance of the tasks writing on the quality of learning endorsed.

Key-words: High education, University teachers' education, Teachers' competences, Pedagogical practices, Science education research. 